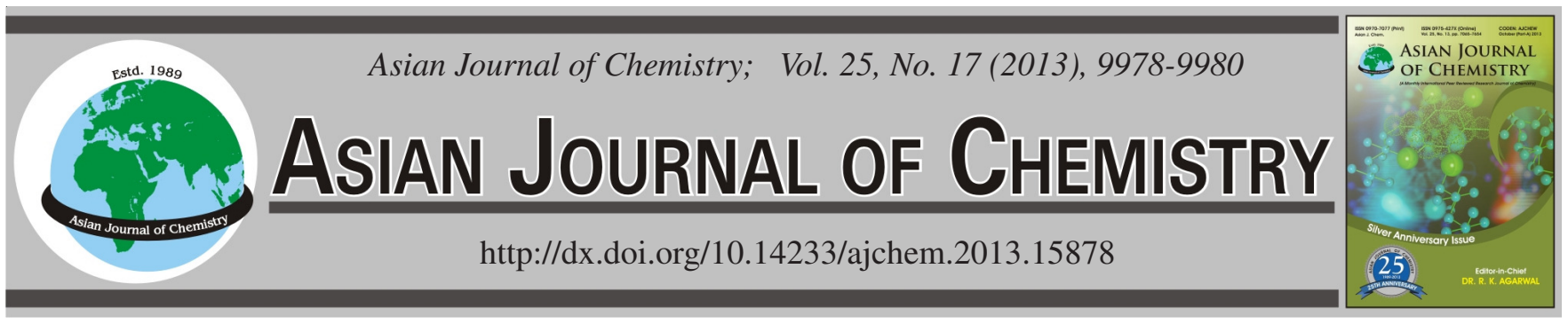

\title{
Synthesis and Crystal Structure of 6-Ethoxy-4'-chloro-2,2'- [ethylenedioxybis(nitrilomethylidyne)]diphenol
}

\author{
W.-K. Dong ${ }^{*}$, L. Xu, X.-Y. Dong, G. Li, M.-M. ZhaO and J.-J. Wu
}

School of Chemical and Biological Engineering, Lanzhou Jiaotong University, Lanzhou 730070, P. R. China

*Corresponding author: E-mail: dongwk@126.com

The molecule of 6-ethoxy-4'-chloro-2,2'-[ethylenedioxybis(nitrilomethylidyne)]diphenol with the molecular formula $\mathrm{C}_{18} \mathrm{H}_{19} \mathrm{~N}_{2} \mathrm{O}_{5} \mathrm{Cl}$, adopts a V-shaped configuration, in which the benzene units are approximately perpendicular, making a dihedral angle of $78.97(3)^{\circ}$. Intramolecular $\mathrm{H}$-bonds are formed between the $\mathrm{OH}$ groups and the oxime $\mathrm{N}$ atoms. In the crystal structure, each molecule links other neighbouring molecules by intermolecular $\mathrm{C}-\mathrm{H} \cdots \mathrm{O}$ and $\mathrm{C}-\mathrm{H} \cdots \pi$ hydrogen-bonding interactions into an infinite $1 \mathrm{D}$ supramolecular chain and the corresponging rectangular pore canal along a-axis.

Key Words: Asymmetric Salamo-type compound, Synthesis, Crystal Structure.

\section{INTRODUCTION}

Salen-type compounds constitute an important class of ligands which have been extensively investigated in modern coordination chemistry ${ }^{1}$. The development of their bisoxime analogues and their metal complexes can provide new topologies for functional materials, in which coordination forms and functionality are significant variables ${ }^{2}$. Due to their facile synthesis and easily tunable steric, electronic and catalytic properties can be used to acquire non-linear optical materials ${ }^{3}$, biological systems ${ }^{4}$, interesting magnetic properties ${ }^{5}$. They are also useful in constructing supramolecular structures ${ }^{6}$. Thus, new materials can be produced by using these compounds, which seem to be suitable candidates for further chemical modifications ${ }^{7,8}$. Herein, we reported on the synthesis and crystal structure of 6-ethoxy-4'-chloro-2,2'-[ethylenedioxybis(nitrilomethylidyne)]diphenol.

\section{EXPERIMENTAL}

5-Chlorosalicylaldehyde and 3-ethoxy-2-hydroxy benzaldehyde were purchased from Alfa Aesar and used without further purification. The others are the same as reported in literature ${ }^{9}$.

General procedure: The major reaction steps involved in the synthesis of the title compound are given in Scheme-I. 6-Ethoxy-4'-chloro-2,2'-[ethylenedioxybis(nitrilomethylidyne)]diphenol was synthesized according to an analogous method reported earlier ${ }^{9,10}$. Yield: $72.6 \%$. m.p. 400-402 K. Anal. calcd. for $\mathrm{C}_{18} \mathrm{H}_{19} \mathrm{~N}_{2} \mathrm{O}_{5} \mathrm{Cl}(\%)$ : C, 57.07; H, 5.06; N, 7.40. Found: C, $56.91 ; \mathrm{H}, 5.01 ; \mathrm{N}, 7.49$.

Pale-green needle-like single crystals suitable for X-ray diffraction studies were obtained after one month by slow evaporation from a methanol/acetone (3:4) solution of the title compound.<smiles>CCOc1cccc(C=O)c1O</smiles><smiles>CCOc1cccc(C=NOCCON=Cc2cc(Cl)ccc2O)c1O</smiles>

Scheme-I: Synthetic route to the asymmetrical Salamo-type compound 
X-Ray structure determination: The X-Ray structure determination of the title compound is the same as reported early ${ }^{9}$. Details of the data collection and refinements of the title compound are listed in Table-1.

\begin{tabular}{ll}
\multicolumn{2}{c}{ TABLE-1 } \\
\multicolumn{1}{c}{ CRYSTAL DATA AND STRUCTURE REFINEMENT } \\
FOR THE TITLE COMPOUND \\
\hline Empirical formula & $\mathrm{C}_{18} \mathrm{H}_{19} \mathrm{~N}_{2} \mathrm{O}_{5} \mathrm{Cl}$ \\
Formula weight & 378.80 \\
Temperature $(\mathrm{K})$ & $293(2)$ \\
Wavelength $(\AA)$ & 0.71073 \\
Crystal system & Triclinic \\
Space group & $\mathrm{P}-1$ \\
Cell dimensions, $(\AA$, deg $)$ & $\mathrm{a}=8.9873(8), \mathrm{b}=9.678(1)$, \\
& $\mathrm{c}=11.966(1)$ \\
& $\alpha=70.817(1), \beta=94.962(2)$, \\
& $\gamma=72.429(1)$ \\
Volume $\left(\AA^{3}\right)$ & $937.0(2)$ \\
$\mathrm{Z}$ & 2 \\
Density (calculated) $\left(\mathrm{mg} / \mathrm{m}^{3}\right)$ & 1.343 \\
Absorption coefficient $\left(\mathrm{mm}^{-1}\right)$ & 0.234 \\
$\mathrm{~F}_{\text {(000) }}$ & 396 \\
Crystal size & $0.45 \times 0.35 \times 0.32$ \\
Index ranges & $-10 \leq \mathrm{h} \leq 10,-11 \leq \mathrm{k} \leq 1,-13$ \\
& $\leq 1 \leq 14$ \\
Reflections collected & $5416 / 3294[\mathrm{R}(\mathrm{int})=0.0246]$ \\
Independent reflections & 1219 \\
Data/restraints/parameters & $3294 / 0 / 236$ \\
Goodness of fit indicator & 1.042 \\
$\mathrm{R}[\mathrm{I}>2 \sigma(\mathrm{I})]$ & $\mathrm{R}_{1}=0.0459, \mathrm{wR} \mathrm{R}_{2}=0.0945$ \\
Largest diff. peak and hole $\left(\mathrm{e} \AA^{-3}\right)$ & 0.153 and -0.193 \\
\hline &
\end{tabular}

\section{RESULTS AND DISCUSSION}

X-ray crystallographic analysis reveals the crystal structure of the title compound. The structure is shown in Fig. 1. Selected bond distances and angles are listed in Table-2. Hydrogen bonds for the title compound are listed in Table-3. The structure of the title compound consists of discrete $\mathrm{C}_{18} \mathrm{H}_{19} \mathrm{~N}_{2} \mathrm{O}_{5} \mathrm{Cl}$ molecule, in which all bond lengths and angles are in normal ranges. The molecule is disposed about an V-shaped configuration, in which the two benzene ring units are approximately perpendicular each other, making a dihedral angle of $78.97(3)^{\circ}$.

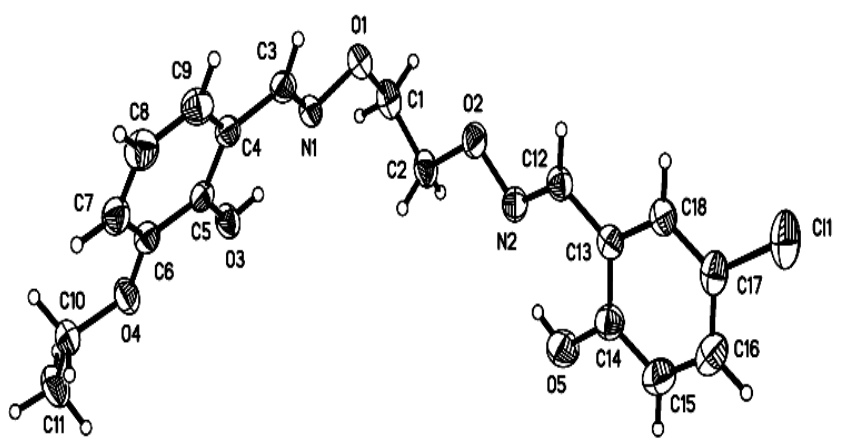

Fig. 1. Molecular structure of the title compound with atom numbering scheme. Displacement ellipsoids for non-hydrogen atoms are drawn at the $30 \%$ probability level

In the crystal structure, there are two weak intramolecular $\mathrm{O}-\mathrm{H} \cdots \mathrm{N}$ hydrogen bonds involving the hydroxyl groups and adjacent oxime $\mathrm{N}$ atoms forming a six-membered ring with a graph motif $\mathrm{S}(6)$. In addition, a pair of intermolecular $\mathrm{C} 7-\mathrm{H} 7 \cdots \pi_{\text {centroid(C13-C18) }}$ hydrogen-bonding interactions link the neighboring two V-shaped molecules, forming a rectangular macrocycle (Fig. 2). Furthermore, these rectangular macrocycles are further linked by a pair of intermolecular $\mathrm{C} 12-\mathrm{H} 12 \cdots \mathrm{O} 3$ hydrogen-bonding interactions into an infinite $1 \mathrm{D}$ chain and the corresponging rectangular pore canal along a axis (Fig. 3) $)^{11-15}$.

TABLE-2

SELECTED BOND DISTANCES $(\AA ̊)$ AND ANGLES $\left({ }^{\circ}\right)$ FOR THE TITLE COMPOUND

\begin{tabular}{|c|c|c|c|c|c|}
\hline Bond & Lengths & Bond & Lengths & Bond & Lengths \\
\hline $\mathrm{Cl1}-\mathrm{C} 17$ & $1.736(3)$ & $\mathrm{O} 4-\mathrm{C} 10$ & $1.440(3)$ & C8-C9 & $1.365(4)$ \\
\hline N1-C3 & $1.271(3)$ & O5-C14 & $1.352(3)$ & C10-C11 & $1.492(3)$ \\
\hline N1-O1 & $1.410(2)$ & $\mathrm{C} 1-\mathrm{C} 2$ & $1.489(3)$ & C12-C13 & $1.455(3)$ \\
\hline N2-C12 & $1.273(3)$ & $\mathrm{C} 3-\mathrm{C} 4$ & $1.451(3)$ & C13-C18 & $1.389(3)$ \\
\hline N2-O2 & $1.399(2)$ & C4-C5 & $1.395(3)$ & C13-C14 & $1.402(3)$ \\
\hline $\mathrm{O} 1-\mathrm{C} 1$ & $1.427(3)$ & C4-C9 & $1.401(3)$ & C14-C15 & $1.383(4)$ \\
\hline $\mathrm{O} 2-\mathrm{C} 2$ & $1.432(2)$ & C5-C6 & $1.398(3)$ & $\mathrm{C} 15-\mathrm{C} 16$ & $1.374(4)$ \\
\hline $\mathrm{O} 3-\mathrm{C} 5$ & $1.359(2)$ & C6-C7 & $1.380(3)$ & C16-C17 & $1.383(4)$ \\
\hline O4-C6 & $1.367(2)$ & $\mathrm{C} 7-\mathrm{C} 8$ & $1.383(3)$ & C17-C18 & $1.373(3)$ \\
\hline Bond & Angles & Bond & Angles & Bond & Angles \\
\hline C3-N1-O1 & $112.8(2)$ & O3-C5-C6 & $117.1(2)$ & C14-C13-C12 & $122.3(2)$ \\
\hline $\mathrm{C} 12-\mathrm{N} 2-\mathrm{O} 2$ & $111.5(2)$ & C4-C5-C6 & $120.4(2)$ & O5-C14-C15 & $117.8(2)$ \\
\hline N1-O1-C1 & $108.4(2)$ & O4-C6-C7 & $125.6(2)$ & O5-C14-C13 & $122.3(2)$ \\
\hline $\mathrm{N} 2-\mathrm{O} 2-\mathrm{C} 2$ & $109.2(2)$ & $\mathrm{O} 4-\mathrm{C} 6-\mathrm{C} 5$ & $115.2(2)$ & C15-C14-C13 & $119.9(2)$ \\
\hline C6-O4-C10 & $117.8(2)$ & C7-C6-C5 & $119.3(2)$ & C16-C15-C14 & $120.7(3)$ \\
\hline $\mathrm{O} 2-\mathrm{C} 2-\mathrm{C} 1$ & $106.8(2)$ & C9-C8-C7 & $120.4(2)$ & C18-C17-C16 & $120.3(2)$ \\
\hline N1-C3-C4 & $120.9(2)$ & C8-C9-C4 & $120.6(2)$ & C18-C17-Cl1 & $119.8(2)$ \\
\hline C5-C4-C9 & $118.7(2)$ & O4-C10-C11 & $107.3(2)$ & C16-C17-Cl1 & $119.9(2)$ \\
\hline C5-C4-C3 & $121.7(2)$ & N2-C12-C13 & $120.7(2)$ & C17-C18-C13 & $120.9(2)$ \\
\hline C9-C4-C3 & $119.6(2)$ & C18-C13-C14 & $118.5(2)$ & - & - \\
\hline $\mathrm{O} 3-\mathrm{C} 5-\mathrm{C} 4$ & $122.5(2)$ & C18-C13-C12 & $119.2(2)$ & - & - \\
\hline
\end{tabular}


TABLE-3

HYDROGEN BONDS $\left[\AA \AA^{\circ}{ }^{\circ}\right]$ FOR THE TITLE COMPOUND

\begin{tabular}{llllll}
\hline $\mathrm{D}-\mathrm{H} \cdots \mathrm{A}$ & $\mathrm{d}(\mathrm{D}-\mathrm{H})$ & $\mathrm{d}(\mathrm{H} \cdots \mathrm{A})$ & $\mathrm{d}(\mathrm{D} \cdots \mathrm{A})$ & $\angle \mathrm{D}-\mathrm{H} \cdots \mathrm{A}$ & Symmetry code \\
\hline O3-H3 $\cdots \mathrm{N} 1$ & 0.82 & 1.89 & $2.607(3)$ & 146 & $\mathrm{x}, \mathrm{y}, \mathrm{z}$ \\
$\mathrm{O} 5-\mathrm{H} 5 \cdots \mathrm{N} 2$ & 0.82 & 1.91 & $2.625(3)$ & 146 & $\mathrm{x}, \mathrm{y}, \mathrm{z}$ \\
$\mathrm{C} 12-\mathrm{H} 12 \cdots \mathrm{O} 3$ & 0.93 & 2.39 & $3.253(3)$ & 154 & $1-\mathrm{x}, 1-\mathrm{y}, 1-\mathrm{z}$ \\
$\mathrm{C} 7-\mathrm{H} 7 \cdots \mathrm{Cg} 1^{\mathrm{a}}$ & 0.930 & 2.85 & $3.672(3)$ & 148 & $-1+\mathrm{x}, \mathrm{y}, \mathrm{z}$ \\
\hline
\end{tabular}

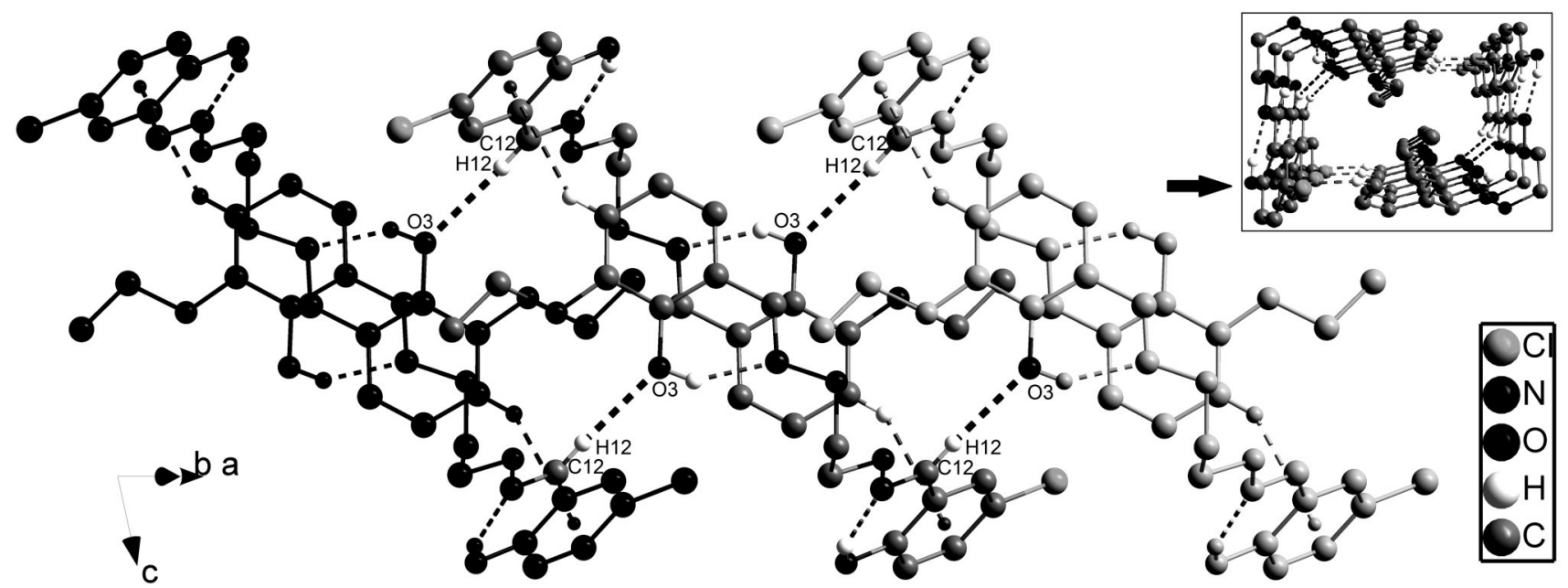

Fig. 3 View of the1D chain linked by $\mathrm{C} 12-\mathrm{H} 12 \cdots \mathrm{O} 3$ hydrogen bonds and the corresponging rectangular pore canal (hydrogen atoms, except those forming hydrogen bonds, are omitted for clarity).

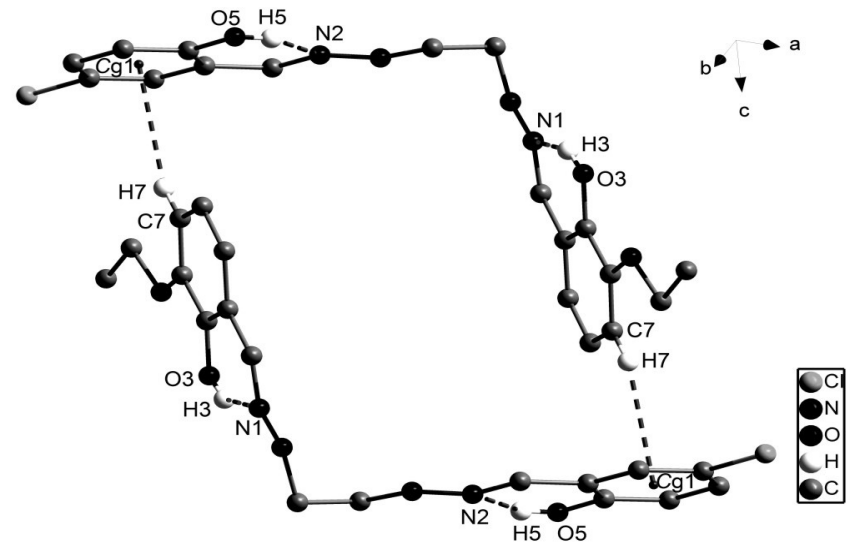

Fig. 2. View of rectangular macrocycle connected by $\mathrm{C} 7-\mathrm{H} 7 \cdots \pi_{\text {centroid(C13-C18) }}$ hydrogen bonding interactions (hydrogen atoms, except those forming hydrogen bonds, are omitted for clarity).

\section{ACKNOWLEDGEMENTS}

This work was supported by the Foundation of Preparative Research of Jin-Chuan Corporation (No. 209125-1102, 1103), the Fundamental Research Funds for the Gansu Province Universities (212086) and the Science and Technology support funds of Lanzhou Jiaotong University (ZC2012003), which are gratefully acknowledged.

\section{REFERENCES}

1. P.G. Cozzi, Chem. Soc. Rev, 33, 410 (2004).

2. R. Ziessel, Coord. Chem. Rev., 216, 195 (2001).
3. H. Miyasaka, N. Matsumoto, H. Okawa, N. Re, E. Gallo and C. Floriani, J. Am. Chem. Soc., 118, 981 (1996).

4. P.G. Lacroix, Eur. J. Inorg. Chem., 339 (2001).

5. T.K. Ronson, H. Adams and M.D. Ward, Inorg. Chim. Acta, 358, 1943 (2005).

6. A.K. Sharma, F. Lloret and R. Mukherjee, Inorg. Chem., 46, 5128 (2007).

7. C. Policar, F. Lambert, M. Cesario and I. Morgenstern-badarau, Eur. J. Inorg. Chem., 12, 2201 (1999).

8. D.A. Atwood and M.J. Harvey, Chem. Rev., 101, 37 (2001).

9. (a) W.K.Dong, K.Q. Li, Y. Zhang, L. Xu, L. Wang and X.Y. Dong, Asian J. Chem., 25, 4398 (2013). (b) W.K. Dong, X.N. He, H.B. Yan, Z.W. Lv, X. Chen, C.Y. Zhao and X.L. Tang, Polyhedron, 28, 1419 (2009). (c) W.K.Dong, X.N. He, H.B. Yan, Z.W. Lv, X. Chen, C.Y. Zhao and X.L. Tang, Polyhedron, 28, 1419 (2009). (d) W.K. Dong, Y.X. Sun, C.Y. Zhao, X.Y. Dong and L. Xu, Polyhedron, 29, 2087 (2010). (e) W.K. Dong, Y.X. Sun, S.J. Xing, Y. Wang and X.H. Gao, Z. Naturforsch, 67b, 197 (2012). (f) W.K. Dong, Y.X. Sun, G.H. Liu, L. Li, X.Y. Dong and X.H. Gao, Z. Anorg. Allg. Chem., 638, 1370 (2012). (g) W.K. Dong, S.J. Xing, Y.X. Sun, L. Zhao, L.Q. Chai and X.H. Gao, J. Coord. Chem., 65, 1212 (2012).

10. S. Akine, T. Taniguchi, W.K. Dong, S. Masubuchi and T. Nabeshima, J. Org. Chem., 70, 1704 (2005).

11. S. Akine, T. Matsumoto, S. Sairenjia and T. Nabeshima, Supramol. Chem., 23, 106 (2011).

12. H.L. Wu, X.C. Huang, J.K. Yuan, F. Kou, F. Jia, B. Liu and Y. Bai, Z. Naturforsch., 66b, 1049 (2011).

13. H.L. Wu, X.C. Huang, J.K. Yuan, F. Kou, F. Jia, B. Liu and K.T. Wang, Eur. J. Med. Chem., 45, 5324 (2010).

14. H.L. Wu, K. Li, T. Sun, F. Kou, F. Jia, J.K. Yuan, B. Liu and B.L. Qi, Transition Met. Chem., 36, 21 (2011).

15. H.L. Wu, F. Jia, F. Kou, B. Liu, J.K. Yuan and Y. Bai, Transition Met. Chem., 36, 847 (2011). 